\title{
Delayed Ischemic Preconditioning Attenuated Renal Ischemia-Reperfusion Injury by Inhibiting Dendritic Cell Maturation
}

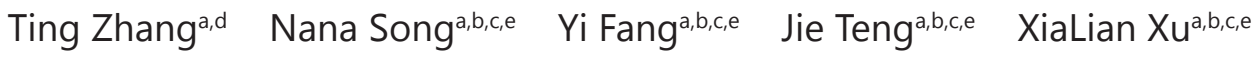 \\ Jiachang Hu,a,b,e Pan Zhang ${ }^{a}$ Rongyi Chen ${ }^{a}$ Zhihui Lu ${ }^{a} \quad$ Xiaofang Yua,b,ce \\ Xiaoqiang Ding ${ }^{a, b, c, e}$
}

aDivision of Nephrology, Zhongshan Hospital, Fudan University, Shanghai, 'bShanghai Medical Center for Kidney Disease, Shanghai, 'Shanghai Key Laboratory of Kidney and Hemodialysis, Shanghai, dDepartment of Nephrology, General Hospital of Ningxia Medical University, Ningxia, eShanghai of Institute Kidney and Dialysis, Shanghai, PR China

\section{Key Words}

Acute kidney injury • Delayed Ischemic Preconditioning • Ischemia-Reperfusion • Dendritic cells

\begin{abstract}
Background/Aims: Even though delayed ischemic preconditioning (DIPC) has been reported to produce renal protection, the underlying mechanism remains poorly understood. We reported that a 15-minute renal ischemic preconditioning (IPC) 4 days before subsequent ischemia-reperfusion attenuated renal injury. Kidney dendritic cells (DCs) are abundant in the renal tubulointerstitium and, depending on their status, can induce immune activation or tolerance. The aim of the present study was to investigate the role of DCs in IPC of the kidney. Methods: Mouse kidneys were challenged by transient brief episodes of sublethal ischemia followed by subsequent prolonged ischemia. DC abundance and maturation in the spleen and kidney were measured by flow cytometry and immunohistochemical staining. To confirm the function of mature DCs in the renoprotective effect of IPC on renal ischemia-reperfusion injury, the A2 adenosine receptor (A2AR) antagonist SCH58261 was administered to stimulate DC maturation prior to assessment of renal functional and histological injury and the inflammatory reaction. Results: Compared with sham-operated animals, preconditioned mice had a reduced injury with less CD11 ${ }^{+}$cells, lower levels of the pro-inflammatory cytokine IL-17 and reduced expression of the mature DC marker CCR7. Preconditioned mice also produced more of the anti-inflammatory cytokine IL-10. Both renal cells and splenocytes from these mice had more DCs (CD45 $\left.{ }^{+} / \mathrm{CD} 11 \mathrm{C}^{+} / \mathrm{F} 4 / 80^{-}\right)$, but fewer of these DCs were mature $\left(\mathrm{CD} 45^{+} / \mathrm{CD}_{11 \mathrm{C}^{+}} /\right.$ $\mathrm{F} 4 / 80^{-} / \mathrm{MHC}^{-\mathrm{II}^{+}} / \mathrm{CD}^{\circ} 0^{+}$) compared with those from sham-treated animals, suggesting that

T. Zhang and N. Song contributed equally to this work.

Xiaoqiang Ding

and Xiaofang Yu

Division of Nephrology, Zhongshan Hospital, Fudan University, Shanghai (PR China) Tel. +86-021-64041990, E-Mail ding.xiaoqiang@zs-hospital.sh.cn, yu.xiaofang@zshospital.sh.cn
\end{abstract}

\section{KARGER}




\section{Cellular Physiology Cell Physiol Biochem 2018;46:1807-1820 and Biochemistry Published online: April 30, $2018 \quad \begin{aligned} & \text { D 2018 The Author(s). } \\ & \text { www.karger.com/cpb }\end{aligned}$ \\ Zhang et al.: Delayed Ischemic Preconditioning Inhibits the Maturation of Dendritic Cells}

the immunomodulatory effect of renal ischemic preconditioning is both local and systemic. Additionally, injection of the A2AR antagonist SCH58261 reversed IPC-induced inhibition of DC maturation and mitigated the protective effect of preconditioning, suggesting that DC maturation contributes to immune cell-mediated ischemic preconditioning. Conclusion: Our results show that DIPC of the kidney provides local and systemic immunosuppression by inhibiting DC maturation and hence mediates a renal protective effect.

\section{Introduction}

Published by S. Karger AG, Basel

Acute kidney injury (AKI) is a common critical illness with a high incidence and high risk of mortality [1]. In 2015, AKI occurred in approximately 13.3 million people, and AKI itself contributes to approximately 1.7 million deaths per year [2]. Among patients who survive, $50 \%$ develop chronic kidney disease, and $8.1 \%$ of these patients progress to end-stage renal disease and require dialysis or transplantation, resulting in a heavy social burden. However, there are no effective therapies available for the prevention of AKI onset or progression [3]. Therefore, there is an urgent need to identify methods to prevent and control AKI.

Ischemic preconditioning (IPC) refers to transient brief episodes of sublethal ischemia before a subsequent prolonged ischemia, which has been shown to increase organ resistance to ischemic injury (ischemic tolerance). IPC represents an endogenous adaptive response that provides local protection against subsequent ischemia/reperfusion (I/R) injury (IRI). Accumulated evidence has indicated the beneficial effects of IPC on diverse organs and tissues including the heart, brain, liver and kidney [4-7]. According to the time window of protection, IPC has been divided into acute IPC (occurring immediately and lasting for 1-2 hours) and delayed IPC (DIPC, occurring 24-48 hours after the IPC stimulus and lasting for several days even weeks) $[8,9]$. Both acute IPC and DIPC are protective, however, a metaanalysis of animal studies showed that DIPC is more effective than acute IPC in reducing renal IRI [10]. Our previous study also demonstrated that IPC could reduce renal IRI when conducted 4 days before index ischemia $[7,11]$. However, the underlying mechanisms remain elusive.

Inflammation plays a major role in the pathophysiology of AKI resulting from ischemia [12]. Dendritic cells (DCs) are a major component of immunocytes in the kidney and are key initiators and effectors of the innate immune system, acting as immune sentinels and antigen-presenting cells to bridge innate and adaptive immunity [13]. DCs are important for the induction of both immune tolerance and activation. Immature DCs induce tolerance by promoting the secretion of TGF- $\beta$ and IL-10; however, mature DCs initiate immunity [14, 15]. It has been reported that spleen DCs mediate immune suppression, which plays an important role in tolerance induction in renal DIPC [16]. Thus, we hypothesized that renal DIPC induces changes to both renal and splenic DCs phenotypes, and these changes might be important in mediating the renal protective effect.

The current studies were undertaken to determine the role of DCs in DIPC of the kidney. We compared the renal and splenic immunophenotypes, including the percentage of leukocytes (CD45 $), \mathrm{F} 4 / 80^{-} \mathrm{DCs}\left(\mathrm{CD} 45^{+} / \mathrm{CD} 11 \mathrm{c}^{+} / \mathrm{F} 4 / 80^{-}\right)$and mature $\mathrm{F} 4 / 80^{-} \mathrm{DCs}\left(\mathrm{CD}^{-} 5^{+} /\right.$

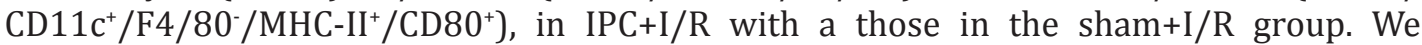
also determined the secretion of anti-inflammatory (IL-10, TGF- $\beta$ ) and pro-inflammatory cytokines (IL-17, TNF- $\alpha$ ) in the kidney. In addition, to examine the role of DC maturation in an immune-regulation mechanism of renal DIPC, we used the A2AR antagonist SCH58261 to inhibit DC maturation. Our results showed that DIPC protects the kidney from IRI by increasing the renal and splenic F4/80- DC subset with reduced maturity and stimulating DC maturation by SCH58261 attenuated the renal protective effect of DIPC. Thus, we concluded that DIPC of the kidney provides local and systemic immunosuppression by inhibiting DC maturation and hence mediating the renal protective. Further studies identifying the precise immunologic mechanisms of DIPC may promote the development of various strategies in the treatment of AKI. 


\section{Cellular Physiology Cell Physiol Biochem 2018;46:1807-1820 \begin{tabular}{c|l} 
DOI: 10.1159/000489366 & $\begin{array}{l}\text { () 2018 The Author(s). Published by S. Karger AG, Basel } \\
\text { www.karger.com/cpb }\end{array}$
\end{tabular} \\ Zhang et al.: Delayed Ischemic Preconditioning Inhibits the Maturation of Dendritic Cells}

\section{Materials and Methods}

Animals

Male C57BL/6 mice (16 weeks, weighing 25-30 g) were obtained commercially (Animal Center of Fudan University, Shanghai, China) and housed in acrylic cages with shredded corn cob bedding in an acclimatized room (12/12 h light/dark cycle; $\left.22 \pm 3{ }^{\circ} \mathrm{C}\right)$ and provided water and mouse breeder chow ad libitum, according to standard protocols for animal care. The procedures used were approved by the Institutional Animal Care and Use Committee of Fudan University and adhered strictly to the National Institutes of Health Guide for the Care and Use of Laboratory Animals.

\section{Mouse models of delayed renal IPC and I/R}

The animals were randomly divided into the following 3 groups: sham+sham, IPC+sham and IPC+I/R. IPC was performed as described previously [7]. Briefly, after mice were anesthetized with a mixture of xylazine $(15 \mathrm{mg} / \mathrm{kg})$ and ketamine $(120 \mathrm{mg} / \mathrm{kg})$ via intraperitoneal injection, bilateral renal pedicles were clamped for $15 \mathrm{~min}$. Mice were maintained at $37^{\circ} \mathrm{C}$, and the abdominal cavity was hydrated with salinemoistened gauze. Sham mice underwent the same surgical procedures, except that the renal pedicles were not clamped. Four days after IPC or sham surgeries, mice were subjected to the I/R operation (30-min occlusion of bilateral renal pedicles or sham operation followed by reperfusion for $24 \mathrm{~h}$ )[17] after which the kidney or spleen were harvested for the following experiment.

For administration of the A2AR antagonist SCH58261, animals were randomly divided into the following 4 groups: DMSO+IPC+I/R, SCH(1 mg)+IPC+I/R, SCH(2 mg)+IPC+I/R, or SCH(5 mg)+IPC+I/R. Accordingly, different does of SCH58261 (1, 2 or $5 \mathrm{mg} / \mathrm{kg}$ body weight) or DMSO (vehicle control) were injected intraperitoneally $30 \mathrm{~min}$ before I/R operation.

\section{Preparation of Single-Cell Suspensions from Kidney and Spleen}

Single cell suspensions of kidney and spleen cells were prepared as described previously [9]. Briefly, renal tissue was minced into small pieces, followed by digestion and disruption in a 5-ml DMEM mixture containing $0.1 \%$ collagenase type I for 1 hour at $37^{\circ} \mathrm{C}$ to obtain a single-cell suspension. The suspension was passed through a 200 mesh $(74 \mu \mathrm{m})$ filter into a $15-\mathrm{mL}$ tube and was centrifuged at $1200 \mathrm{rpm}(300 \mathrm{~g})$ for 5 min. The resulting pellet was incubated in red blood cell lysis buffer to remove red blood cells.

\section{Flow cytometry}

To measure the abundance and maturity of dendritic cells in kidney and spleen samples, single cell suspensions of kidney and spleen tissues were blocked by incubation with anti-mouse CD16/CD32 purified antibody (eBioscience, USA) and then stained using the following fluorochrome-labelled antibodies: Anti-

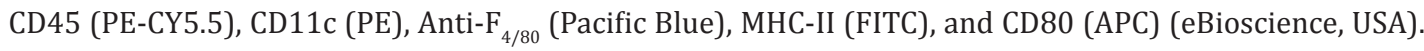
The cells were again rinsed twice with wash buffer prior to flow cytometry analysis, which was conducted using an Invitrogen Attune NxT Flow Cytometer (Thermo Fisher Scientific, USA). Flow cytometry data were analysed using FlowJo 10.0 software.

\section{Histopathological Examinations and Immunohistochemical Staining}

Kidney slices were fixed in $10 \%$ formalin, embedded in paraffin, cut into 5 - $\mu \mathrm{m}$ sections, and stained with a Haematoxylin-Eosin (HE) staining Kit or a CD11c antibody. For HE staining, histologic injury scores were evaluated under light microscopy by a pathologist blinded to the origin of the preparation and determined using a previously described scoring system. Injury was scored according to the percentage of damaged tubules (cell necrosis, loss of brush border, tubule dilation, cast formation, inflammatory cell infiltration) as follows: no injury (0), mild: less than $25 \%$ (1), moderate: less than $50 \%$ (2), severe: less than $75 \%$ (3), and very severe: more than 75\% (4). Immunohistochemical staining was performed as described previously [18]. After incubation first with an antibody against CD11c (1:100, eBioscience, USA), the reaction was detected with Cy3-labeled Donkey Anti-Goat IgG (H+L) (Santa Cruz, USA) and examined using light microscopy. The IOD (integrated optical density) values of positively stained cells were calculated in six representative sections from each animal in a blinded manner and using ImageJ software.

\section{Western blotting}

Renal tissues were homogenized in ice-cold lysis buffer containing protease and phosphatase inhibitors. The supernatant was collected after centrifugation at $12,000 \mathrm{~g}$ for $15 \mathrm{~min}$ at $4^{\circ} \mathrm{C}$. Western blotting was performed as previously described [19]. Samples (60 $\mu$ g protein per lane) were loaded and separated on 


\section{Cellular Physiology Cell Physiol Biochem 2018;46:1807-1820

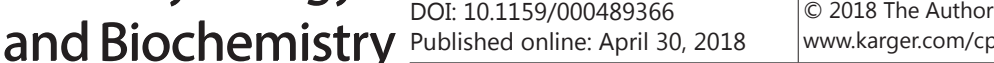 \\ Zhang et al.: Delayed Ischemic Preconditioning Inhibits the Maturation of Dendritic Cells}

a sodium dodecyl sulphate-polyacrylamide gel and transferred to a PVDF membrane. The membrane was blocked with 5\% nonfat milk and incubated with the primary antibodies against CCR-7 (1:1000) and GAPDH (1:10000) overnight at $4{ }^{\circ} \mathrm{C}$ and then incubated with HRP-conjugated secondary antibodies and developed using a chemiluminescent Horseradish Peroxidase Substrate. The results were normalized to GAPDH.

Analysis of Plasma Creatinine

Blood samples were obtained via cardiac puncture at the indicated times. Plasma creatinine was measured using the improved Jaffe method (Quantichrom creatinine Assay Kit, BioAssay Systems, Hayward, CA) [20].

\section{Enzyme-Linked Immunosorbent Assay}

Kidney tissues were homogenized in PBS and centrifuged to obtain supernatants. Supernatant protein concentrations were measured using a BCA protein assay kit and adjusted to $2 \times 10^{4} \mu \mathrm{g} / \mathrm{ml}$ by PBS. The levels of IL-10, TGF- $\beta$, IL-17 and TNF- $\alpha$ were detected using commercially available enzyme-linked immunosorbent assay (ELISA) kits (R\&D Systems, Minneapolis, MN) according to the manufacturer's protocol.

\section{$P C R$}

Total RNA was isolated from MMSCs using TRIzol (Life Technologies, USA). The RNA levels of CCR7 (Forward: 5'-CCCCATCCCACTTATAACTACCTCAA-3', Reverse: 5'-TGGCAGCCTCTCACTTTCACTTTT-3', 236 bp) and 18s (Forward: 5'-GGCTACCACATCCAAGGAA-3', Reverse: 5'-CCTGTATTGTTATTTTTCGTCACTAC, 86 bp) were detected using a SYBR-Green RT-qPCR kit (Takara, Japan) according to the manufacturer's instructions (Sangon Biotech, China). The mRNA expression levels were normalized to that of 18s. Simple relative quantification of target gene expression normalized to $18 \mathrm{~s}$ was performed using the $2^{-\Delta \Delta \mathrm{Ct}}$ method.

\section{Statistics}

Data are presented as the means \pm SD and were analysed using SPSS software. Statistical analyses including the independent t-test (comparison of two groups) and one-way ANOVA followed by Tukey's post hoc test (comparison of more than two groups) were regarded as significant when $\mathrm{p}<0.05$.

\section{Results}

Delayed Ischemic Preconditioning Attenuated the Renal Ischemia-Reperfusion Injury Functionally and Histologically

The delayed kidney ischemic preconditioning strategy was performed as shown in Fig. 1A. I/R-induced tubular injury was characterized by tubular cell necrosis, dilation of tubules, and cast formation in the outer medulla. As expected, delayed kidney ischemic preconditioning significantly attenuated I/R-induced kidney injury (Fig. 1B-D). Kidneys from preconditioned ischemic animals showed less tubular injury compared with shamtreated animals (Fig. 1C).

\section{Delayed Ischemic Preconditioning Suppressed Renal Immune Reaction}

To examine whether DIPC induced renoprotection is mediated by their immunomodulation, we measured the number of CD11c-positive cells, expression of CCR7 (marker of mature DCs), and secretion of anti-inflammatory (IL-10, TGF- $\beta$ ) and proinflammatory cytokines (IL-17, TNF- $\alpha$ ). We observed that the abundance of CD11c-positive cells present in the kidney mesenchyme increased after IRI. Compared with the sham $+\mathrm{I} / \mathrm{R}$ group, the number of CD11c-positive cells decreased significantly in kidneys from the IPC+I/R group (Fig. 2A and B), and this effect was accompanied by lower protein and RNA levels of CCR-7, higher levels of IL-10 and lower levels of IL-17 in the IPC+I/R kidneys than in the sham+I/R kidneys (Fig. 2C-I).

Delayed Ischemic Preconditioning Suppressed Renal Immune Reaction by Inhibiting DC Maturation

Since the major population of CD11c-positive cells described thus far is the F4/80expressing macrophages [21], for a higher level of resolution, sorted CD45-positive, CD11c- 


\section{Cellular Physiology and Biochemistry}

Cell Physiol Biochem 2018;46:1807-1820 \begin{tabular}{l|l}
\hline DOI: $10.1159 / 000489366$ & (C) 2018 The Author(s). Published by S. Karger AG, Base
\end{tabular}

Zhang et al.: Delayed Ischemic Preconditioning Inhibits the Maturation of Dendritic Cells

Fig. 1. Renal protective effect of delayed ischemic preconditioning. A: Following sham or IPC (15-min ischemia) operation on day 1 , an I/R (35 min ischemia) injury was induced on day 5, and animals were sacrificed for various analyses on day 6. B: Serum concentration of creatinine (Cr) after I/R. Serum $\mathrm{Cr}$ was significantly decreased in the preconditioned mice. C: Kidney histology, HE staining, $\times 200$. D: Renal acute tubulointerstitial injury score was quantified according to HE staining. ${ }^{*} \mathrm{P}<0.05$ compared with sham + sham, ${ }^{*} \mathrm{P}<0.05$ compared with sham $+\mathrm{I} / \mathrm{R}, \mathrm{n}=6$ per group.

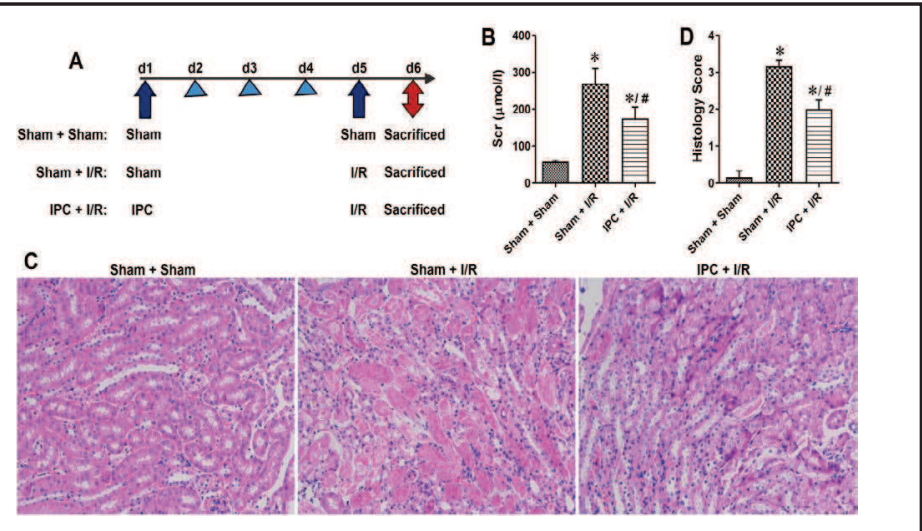

Fig. 2. Effect of delayed ischemic preconditioning on renal inflammation. Procedures were performed as shown in Fig. 1. A: Immunofluorescence staining for CD11c, photographed at $\times 200$ magnification and $\times 400$ for detail. The number of CD11c-positive cells was significantly increased in sham $+I / R$ mice and decreased in IPC + I/R mice. B: IOD (integrated optical density) of CD11c-positive stained cells were calculated. C-E: CCR7 protein and RNA levels were decreased in IPC + I/R mice compared with those in sham $+I / R$ mice. F-I: anti-inflammatory cytokine IL-10 was significantly increased and pro-inflammatory cy-

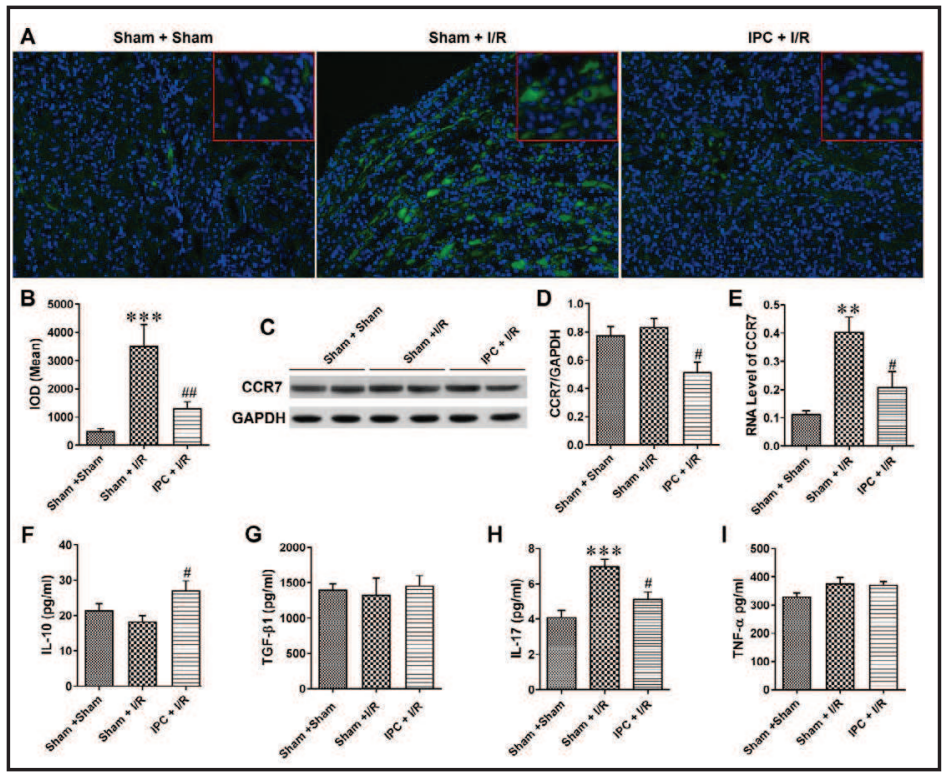
tokine IL-17 was decreased in the preconditioned mice. ${ }^{* *} \mathrm{P}<0.01,{ }^{* * *} \mathrm{P}<0.001$ compared with sham + sham, ${ }^{*} \mathrm{P}<0.05$ compared with sham + $\mathrm{I} / \mathrm{R}, \mathrm{n}=6$ per group.

positive, F4/80-negative cells from mouse kidneys were further analysed for expression of the two DC maturation markers MHCII and CD80. To demonstrate the effect of DIPC on kidney DCs, we obtained renal cells from animals $24 \mathrm{~h}$ after a second I/R procedure and examined the immune phenotypes. We determined the percentages of leukocyte (CD45 $)$, DCs $\left(\mathrm{CD} 45^{+} /\right.$

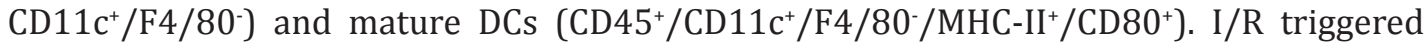
renal inflammation by increasing the percentage of leukocytes, however, DIPC failed to suppress leukocyte infiltration (Fig. 3B-C). To assess whether the beneficial effect of DIPC is involved with the induction of immune tolerance by DCs, we compared the percentage of total DCs and mature DCs between sham $+\mathrm{I} / \mathrm{R}$ and IPC+I/R animals. The percentages of total DCs decreased in both sham + I/R and IPC+I/R animals compared with those in sham+sham animals. Additionally, IPC slightly increased DC infiltration in I/R kidneys but this difference was not significant compared with the sham+I/R group (Fig. 3D-E). By contrast, IPC significantly inhibited DC maturation in the I/R kidneys compared with that in the sham $+\mathrm{I} / \mathrm{R}$ kidneys (Fig. 3F-G). Since DIPC had a mild effect on total DC infiltration and decreased the 


\section{Cellular Physiology}

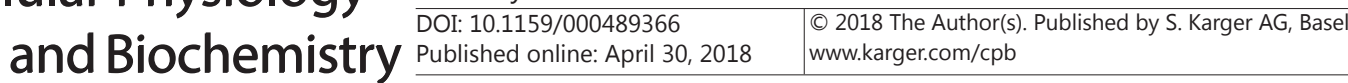

Zhang et al.: Delayed Ischemic Preconditioning Inhibits the Maturation of Dendritic Cells

percentage of mature DCs, we concluded that DIPC protects against renal IRI by suppressing DC maturation, which induces immune activation and increasing abundance of tolerogenic DCs (immature DCs).

Delayed Ischemic
Preconditioning
Induced Systemic
Immune Tolerance
Our previous study indicated that brief ischemia and reperfusion in kidney can provide protection against organ injury at local and remote sites [22]. Many other observations have also suggested that the preconditioning effect is systemically mediated [23, 24]. To determine the effect of renal IPC on the systemic immune response, we measured the percentages of leukocytes (CD45+), DCs (CD $\left.45^{+} / \mathrm{CD} 11 \mathrm{c}^{+} / \mathrm{F} 4 / 80^{-}\right)$ and mature DCs $\left(\mathrm{CD}^{\circ} 5^{+}\right)$ CD $11 \mathrm{c}^{+} / \mathrm{F} 4 / 80 \% / \mathrm{MHC}-$ $\mathrm{II}^{+} / \mathrm{CD}^{+} 0^{+}$in the spleen. The results showed that even $I / R$ or $I P C+I / R$ had no effect on leukocyte populations (Fig. 4A and B). DC percentages decreased in splenocytes from I/Rtreated mice. However, the percentage of DCs increased significantly in the spleen from IPC+IR mice compared with that in sham $+\mathrm{I} / \mathrm{R}$ mice (Fig. 4C and D). By contrast, the percentage of DCs expressing the mature markers MHC-II and CD80 $0^{+}$was lower in the spleen from IPC+IR animals than sham+I/R animals (Fig. 4E and F). These results suggest that renal IPC induces peripheral immune tolerance by increasing tolerogenic DCs and inhibiting DC maturation.

The A2AR Antagonist SCH58261 Inhibited IPC-induced Immune Tolerance and Was Associated with Loss of IPC Benefits

Since activation of A2AR is critical in generating tolerogenic DCs [13], we injected different doses of the A2AR antagonist SCH58261 (1,2, and $5 \mathrm{mg} / \mathrm{kg}$ body weight) to stimulate

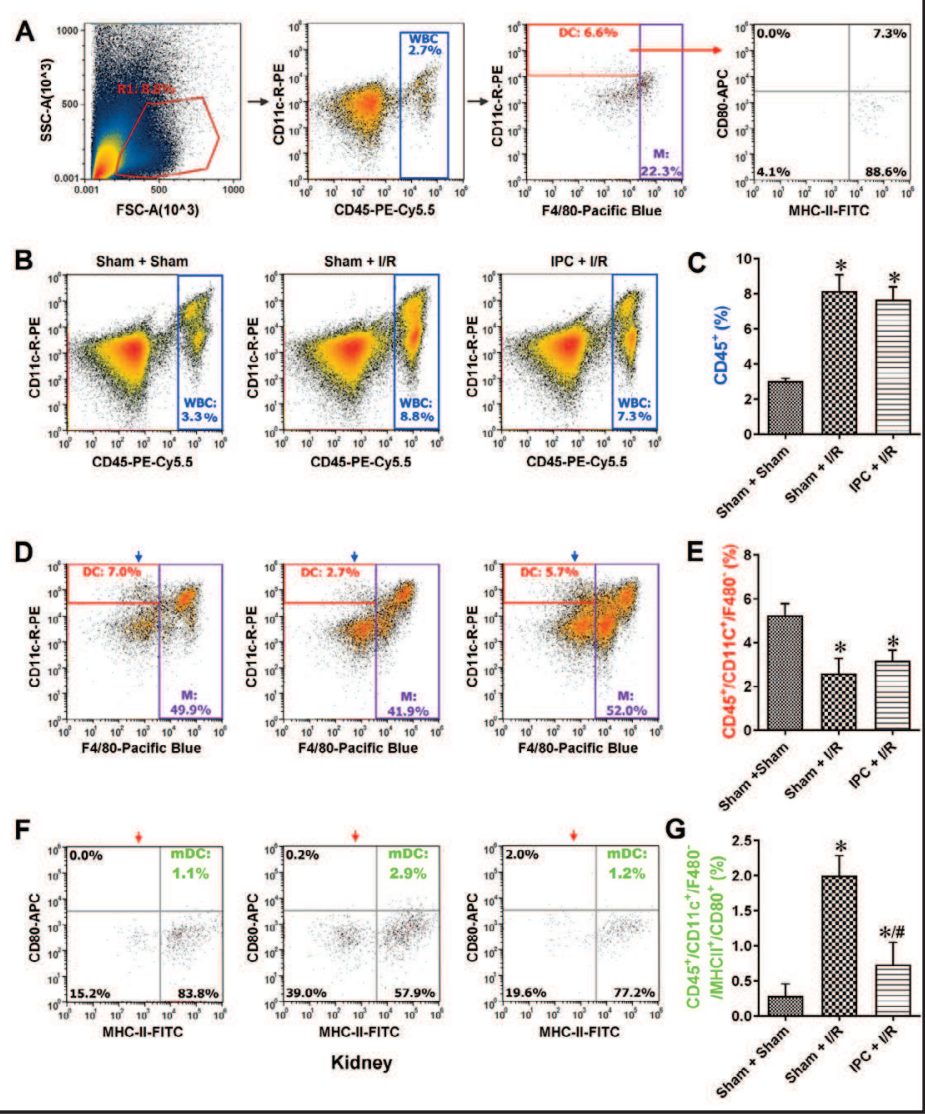

Fig. 3. Delayed ischemic preconditioning attenuated I/R induced DC maturation in the kidney. Procedures were performed as shown in Fig. 1. Single-cell suspensions from the kidney were isolated 24 hours after I/R and measured by flow cytometry. A: Events were first gated on forward and side scatter patterns to eliminate dead cells or debris and then further selected for CD45 (common leukocyte antigen). CD $45^{+}$ gated events were further analysed for expressions of CD11c (dendritic cell marker) and F4/80 (macrophage marker); CD11c ${ }^{+}$/ F4/80 suggested renal DCs. Renal DCs were further analysed for expression of MHC-II' and $\mathrm{CD}^{+} 0^{+}$(mature dendritic cell marker). B-C: leukocytes were increased both in sham $+\mathrm{I} / \mathrm{R}$ and IPC $+\mathrm{I} / \mathrm{R}$ mice. $\mathrm{D}-\mathrm{E}$ : percentage of total DCs was higher in IPC + I/R mice than in sham $+\mathrm{I} / \mathrm{R}$ mice without statistical significance. F-G: percentage of mature DCs was decreased in IPC + I/R mice compared with that in sham $+\mathrm{I} / \mathrm{R}$ mice. ${ }^{*} \mathrm{P}<0.05 \mathrm{com}-$ pared with sham +sham, ${ }^{*} \mathrm{P}<0.05$ compared with sham $+\mathrm{I} / \mathrm{R}, \mathrm{n}=6$ per group. WBC: Leucocyte, DCs: Dendritic Cells, mDCs: mature Dendritic Cells. 


\section{Cellular Physiology and Biochemistry}

Cell Physiol Biochem 2018;46:1807-1820

Zhang et al.: Delayed Ischemic Preconditioning Inhibits the Maturation of Dendritic

Fig. 4. Maturation of splenic DCs is associated with renal I/R injury. Leukocytes, total DCs and mature DCs in single-cell suspensions from the spleen were measured by flow cytometry as shown in Fig. 3. A-B: percentage of leukocyte in the spleen was not changed either in IPC + I/R mice or in sham + I/R mice. C-D: percentage of total DCs was higher in IPC $+\mathrm{I} / \mathrm{R}$ mice than in sham + I/R mice. E-F: percentage of mature DCs was decreased in IPC + I/R mice compared that in with sham $+\mathrm{I} / \mathrm{R}$ mice. ${ }^{* *} \mathrm{P}<0.01$ compared with sham +sham, ${ }^{\#} \mathrm{P}<0.05$ compared with sham + I/R, $n=6$ per group. WBC: Leucocyte, DCs: Dendritic Cells, mDCs: mature Dendritic Cells.

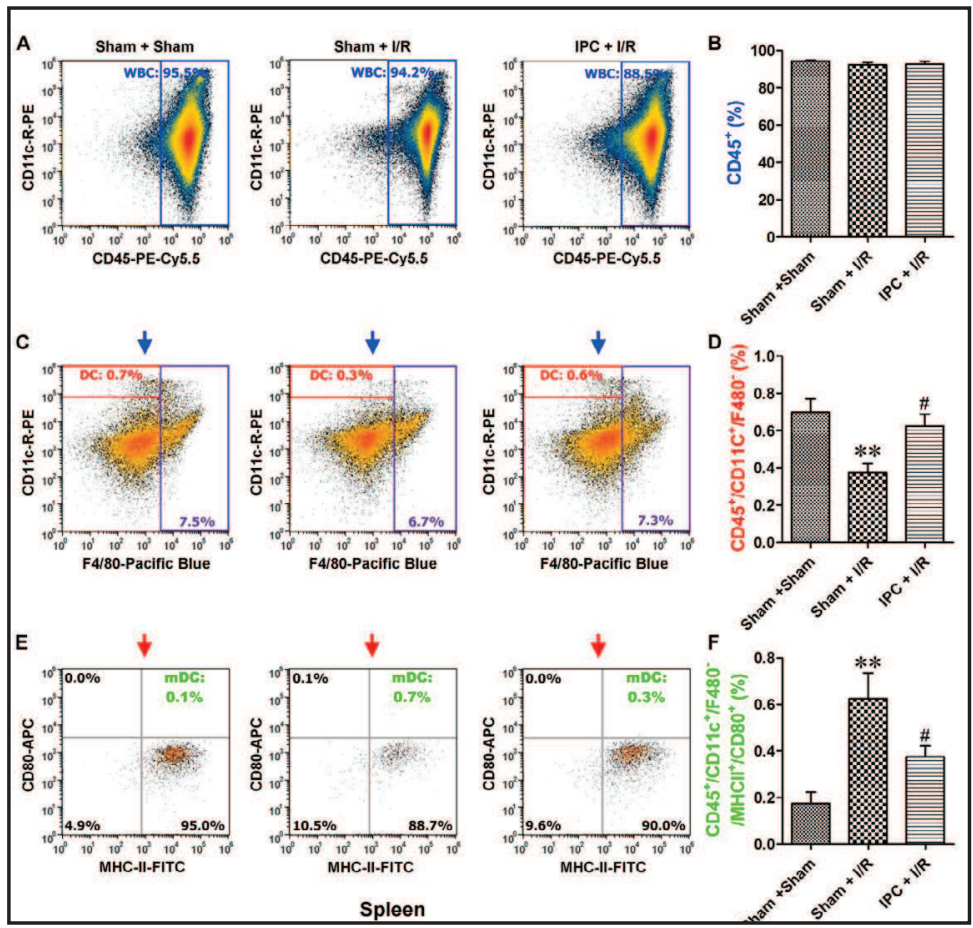

Fig. 5. Effect of SCH58261 administration on renal mononuclear cell phenotypes. A: Following IPC operation on day 1 , DMSO or SCH58261 was injected intraperitoneally on day 5, 30 min before I/R; animals were sacrificed on day 6 , and mononuclear cells from the kidney were obtained for flow cytometry. B-C: administration of SCH58261 had no effect on leukocyte infiltration. D-E: administration of SCH58261 had no effect on total DC infiltration. F-G: SCH58261 promoted maturation of DCs independently. ${ }^{* *} \mathrm{P}<0.01 \quad$ compared with DMSO+IPC+I/R, n=6. WBC: Leukocyte, DCs: Dendritic Cells, mDCs: mature Dendritic Cells.

DC maturation five days after IPC and $20 \mathrm{~min}$ before I/R. As expected, injection

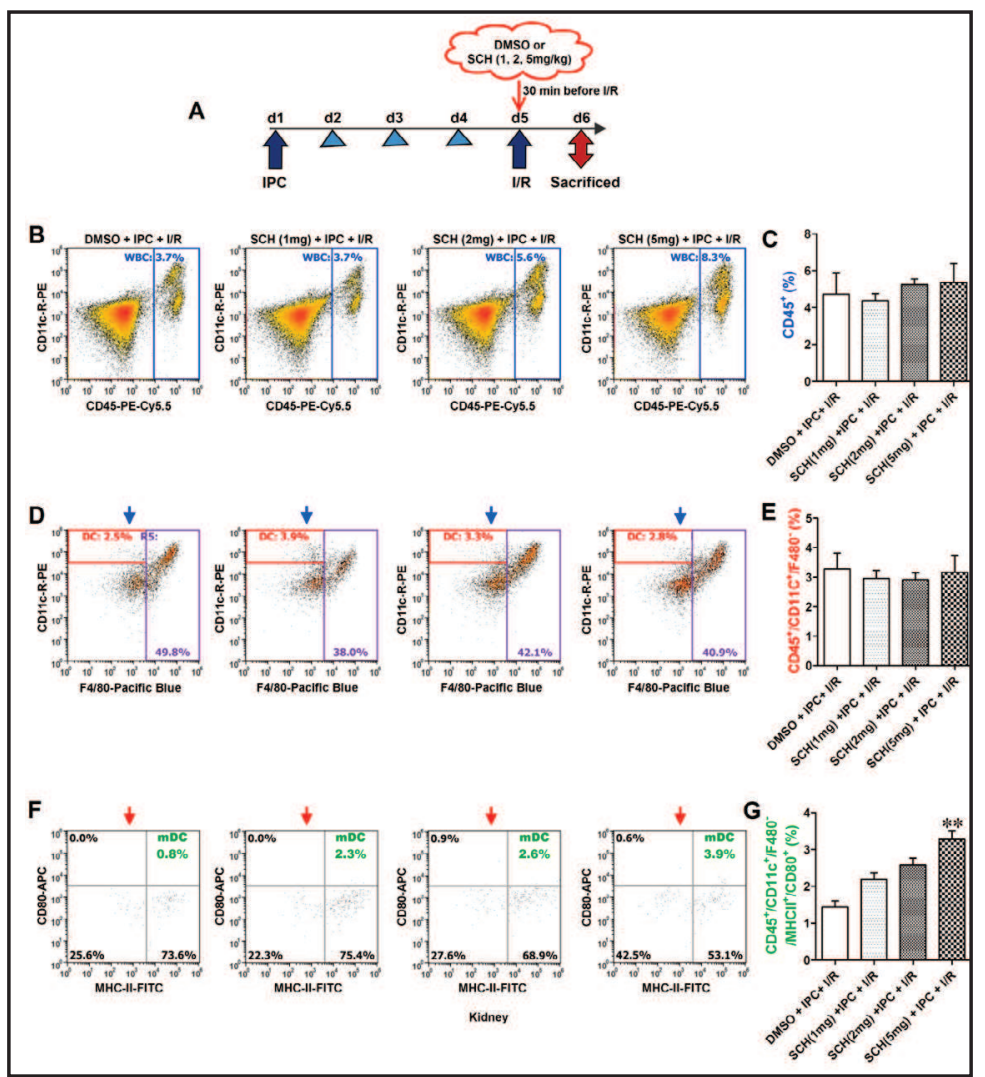
of SCH58261 at 4 days after IPC increased DC maturation in both the kidney and the spleen (Fig. 5 and 6). The antiinflammatory effect of IPC partially disappeared following SCH58261 injection. The number of CD11c-positive cells and the extent of CCR7 expression were notably increased by SCH58261 


\section{Cellular Physiology and Biochemistry}

Cell Physiol Biochem 2018;46:1807-1820 \begin{tabular}{l|l}
\hline DOI: $10.1159 / 000489366$ & (C) 2018 The Author(s). Published by S. Karger AG, Base
\end{tabular} \begin{tabular}{ll} 
Published onlıne: April 30, 2018 www.karger.com/cpb \\
\hline
\end{tabular}

Zhang et al.: Delayed Ischemic Preconditioning Inhibits the Maturation of Dendritic Cells

injection following IPC. The markedly increased renal IL-10 level and increased IL-17 level in preconditioned ischemic kidneys showed partial reversal, suggesting that the beneficial effect of kidney ischemic preconditioning might be partially mediated by DCs (Fig. 7). Systemic improvements in DC maturation before I/R were associated with partial loss of the beneficial effect of IPC on kidney function and histology. The decreased serum creatinine level and tubular damage observed in preconditioned ischemic kidneys was partially reversed by SCH58261 injection following IPC (Fig. 8).

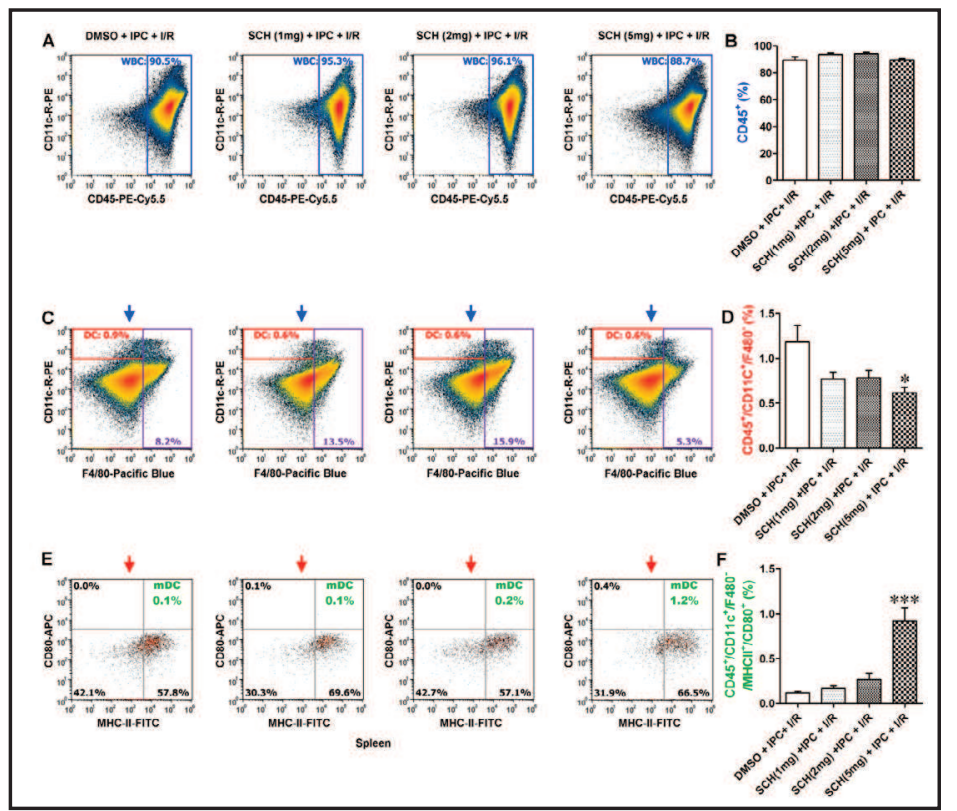

Fig. 6. Effect of SCH58261administration on splenocyte phenotypes. Procedures were performed as in Fig. 6. A-B: administration of SCH58261 had no effect on leukocyte infiltration. C-D: administration of SCH58261 decreased total DC infiltration. E-F: SCH58261 promoted maturation of DCs independently. ${ }^{*} \mathrm{P}<0.05$, ${ }^{* * *} \mathrm{P}<0.001$ compared with DMSO+IPC+I/R, n=6. WBC: Leucocyte, DCs: Dendritic Cells, mDCs: mature Dendritic Cells.

\section{Discussion}

In the present study, we demonstrated the following: (1) DIPC (four days after transient episodes of sublethal ischemia) provided significant renal protection with less tubular injury and inflammatory reactions (less CD11c-positive cells, lower pro-inflammatory cytokine IL-17 and higher anti-inflammatory cytokine IL-10 levels); (2) The renal protective effect of delayed IPC is achieved by mediating the tolerogenic and maturation properties of DCs locally and systemically; (3) At 4 days after tolerogenic $I / R$, DCs from the kidney are thought to be in a less mature stage with low expression of CCR7; DCs from the spleen are also in a more

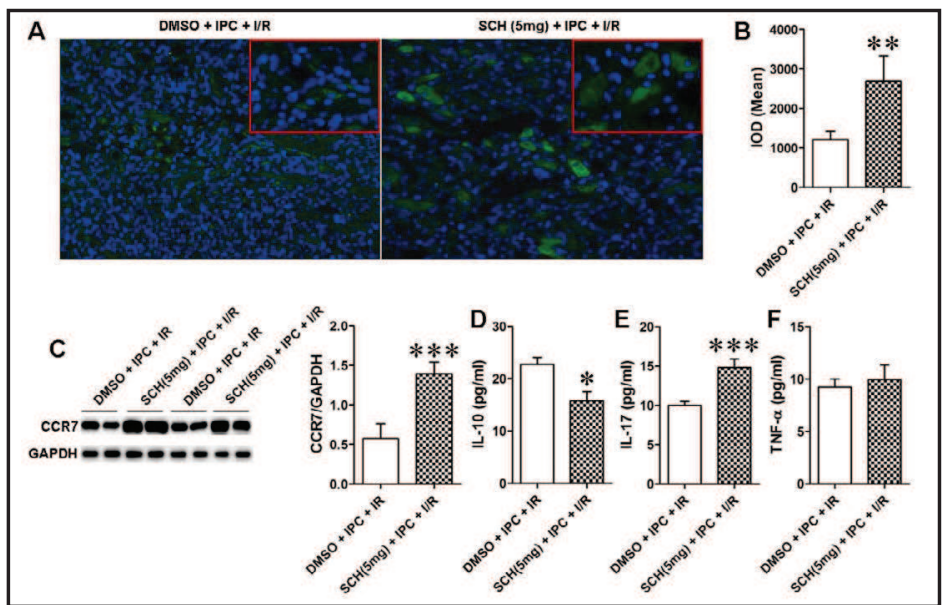

Fig. 7. Effect of SCH58261administration on renal inflammatory reaction. Procedures were performed as in Fig. 6. A: Immunofluorescence staining for CD11c, photographed at $\times 200$ magnification and $\times 400$ for detail. The number of CD11c-positive cells was significantly increased by administration of SCH58261 (5 mg/kg body weight). B: IOD (integrated optical density) of CD11c-positive stained cells were calculated. C: Administration of SCH58261 increased the expression of CCR7. D-F: Administration of SCH58261 decreased secretion of IL-10 and increased that of IL-17. ${ }^{*} \mathrm{P}<0.05,{ }^{* *} \mathrm{P}<0.01,{ }^{* * *} \mathrm{P}<0.001$ compared with DMSO+IPC+I/R, $n=6$. tolerogenic and less mature stage with less surface expression of MHC-II and CD80 (4) Systemic stimulation of matu- 


\section{Cellular Physiology and Biochemistry}

Cell Physiol Biochem 2018;46:1807-1820

Zhang et al.: Delayed Ischemic Preconditioning Inhibits the Maturation of Dendritic Cells

Fig. 8. Effect of SCH58261administration on delayed kidney ischemic preconditioning. Procedures were performed as in Fig. 6. A: Kidney histology, HE staining, $\times 200$. B: Renal acute tubulointerstitial injury score after I/ R. SCH58261 aggravate tubulointerstitial injury in the preconditioned mice. C Serum Cr after I/R. Serum $\mathrm{Cr}$ significantly increased in SCH58261 administered mice. ${ }^{*} \mathrm{P}<0.05,{ }^{* *} \mathrm{P}<0.01$ compared with DMSO+IPC+I/R, \#\# $\mathrm{P}<0.01$ com-

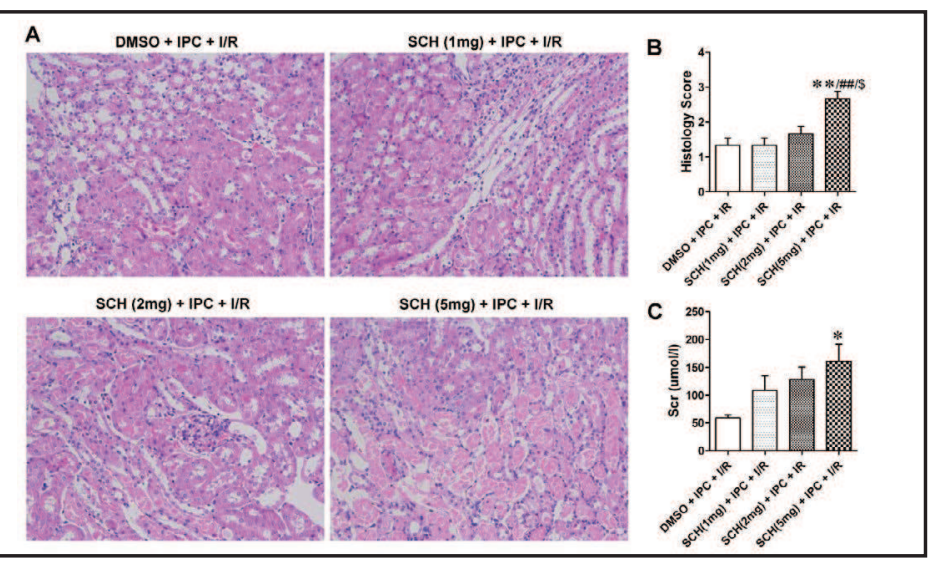
pared with $\mathrm{SCH}(1 \mathrm{mg})+\mathrm{IPC}+\mathrm{I} / \mathrm{R}$, \$ $\mathrm{P}<0.05$ compared with $\mathrm{SCH}(2 \mathrm{mg})+\mathrm{IPC}+\mathrm{I} / \mathrm{R}, \mathrm{n}=6$.

ration of DCs by SCH58261 injection following IPC was associated with partial loss of the beneficial effect of IPC. These results demonstrated that IPC induced both local and systemic immune tolerance characterized by less mature DCs.

DCs were discovered over 40 years ago and are a population of innate immune cells that critically regulate both innate and adaptive immune responses [25]. The ability of DCs to control immune tolerance versus activation has emerged as one of the most fundamental concepts in the field of immunology [26]. DCs have been reported to play significant roles in immunity to pathogens [27], self-tolerance [28], autoimmunity [29], transplant rejection/survival [30], and tumour immunity [31]. Accumulating evidence has demonstrated the pivotal role of DCs in determining both renal tissue injury and subsequent reparative progresses, especially in renal IRI. However, the effect of DCs on IRI is disputed. It was reported that depletion of macrophages and dendritic cells by injection of liposome encapsulated clodronate is protective against renal IRI, however, selective depletion of CD11 $\mathrm{c}^{+}$DCs by injection of DT in CD11c-DTR transgenic mice failed to protect against IRI [32]. In the same CD11c-DTR transgenic mice model, others reported that DT treatment prior to IRI is protective, suggesting that DCs actively contribute to the early innate injurious response in kidney IRI [33]. Macrophage/dendritic cell depletion during the recovery phase increased functional and histologic injury and delayed regeneration, indicating that macrophages/dendritic cells are important to the mechanism mediating renal tubule epithelial regeneration after IRI [34]. Our present research indicated that renal CD11c $\mathrm{c}^{+}$ cells were significantly increased after IRI and inhibiting infiltration of CD $11 \mathrm{c}^{+}$cells by IPC provided renal protection, indicating that $\mathrm{CD} 11 \mathrm{c}^{+}$cells contribute to injurious responses in kidney IRI. Contradictory results in these experiments might be due to different experimental models and different renal microenvironments, which influence the immunological reaction [35]. A further limitation of current studies is that these methods of DC depletion are not completely specific for DCs [36]. How to distinguish between renal macrophages or dendritic cells is an area of controversy. Although the presence of $\mathrm{CD} 11 \mathrm{c}^{+}$cells negative for expression of the macrophage markers F4/80 suggests the presence of myeloid DCs [37, $38], F 4 / 80$ is now recognized to also be expressed on renal resident CD11 $\mathrm{c}^{+} \mathrm{DCs}[39,40]$. However, a substantial number of studies have demonstrated that the CD11 $\mathrm{c}^{+} / \mathrm{F} 4 / 80^{-}$and $\mathrm{CD} 11 \mathrm{c}^{+} / \mathrm{F} 4 / 80^{+}$subsets have distinct effects on recovery and regeneration following IRI. A recent report demonstrated that the $\mathrm{CD} 11 \mathrm{c}^{+} / \mathrm{F} 4 / 80^{+} \mathrm{DCs}$ subset has an anti-inflammatory phenotype and participates in recovery following kidney IRI by modulating the inflammatory response [41]. By contrast, another study provided evidence that resident dendritic cells, specifically $\mathrm{CD} 11 \mathrm{c}^{+} \mathrm{F} 4 / 80^{+} \mathrm{DCs}$, are potent 'first responders' in the innate response to renal IRI [42]. In this study, we observed that the percentage of CD11 $\mathrm{c}^{+} \mathrm{F} 4 / 80^{-} \mathrm{DCs}$ in single cell suspensions from kidneys was increased at $24 \mathrm{~h}$ in ischemic kidneys compared with that 


\section{Cellular Physiology Cell Physiol Biochem 2018;46:1807-1820 and Biochemistry Published online: April 30, $2018 \quad \begin{aligned} & \text { D 2018 The Author(s) } \\ & \text { www.karger.com/cpb }\end{aligned}$ \\ Zhang et al.: Delayed Ischemic Preconditioning Inhibits the Maturation of Dendritic Cells}

in control kidneys. To specifically investigate the subset of DCs relevant to renal IRI, the sorted kidney $\mathrm{CD}^{4} 5^{+} / \mathrm{CD} 11 \mathrm{c}^{+} / \mathrm{F} 4 / 80^{-}$cells were further analysed for the two DC maturation markers MHCII and CD80. We observed that $\mathrm{CD} 11 \mathrm{c}^{+} / \mathrm{F} 4 / 80^{-} \mathrm{DCs}$ expressing the maturation markers MHCII and CD80 were increased following IRI, and IPC exerts renal protection by restoring the IRI induced changes to DC phenotype. These results indicated that maintaining $\mathrm{CD} 11 \mathrm{c}^{+} / \mathrm{F} 4 / 80^{-} \mathrm{DCs}$ in a more mature state is important in the pathogenic processes of IRI. In other words, less mature $\mathrm{CD} 11 \mathrm{c}^{+} / \mathrm{F} 4 / 80$ - DCs might participate in immune cell mediated tolerance in the ischemic kidney.

IPC represents an endogenous adaptive response that protects against subsequent I/R injury, however, the underlying mechanisms have not fully been elucidated. Most studies have focused on the roles of heat shock proteins [43], NO [44, 45], and adenosine [46]. The inflammatory response in the post-ischemic kidney was considered to be a detrimental process in the pathogenesis of renal IRI [47]. DCs constitute an abundant population of leukocytes within the kidney and are crucial players in the development of tolerance and inflammation [48]. Although Cho et al [16]. reported that systemic depletion of CD11 $\mathrm{c}^{+}$cells by liposome clodronate injection before renal IPC was associated with partial loss of the beneficial effect of IPC on the kidney, the role of renal resident DCs cells in IPC-induced renal protection was unclear until now. In our study, we induced bilateral renal IPC in mice and then challenged them with an ischemic insult 4 days later. The initial observations showed that compared with sham-operated controls, preconditioned mice had a reduced injury with less CD11 $\mathrm{c}^{+}$cells and more CD11 $\mathrm{c}^{+} / \mathrm{F} 4 / 80^{-} \mathrm{DCs}$ but with fewer numbers of DCs expressing the maturation markers MHC-II and CD80, suggesting that the protection of renal IPC was associated with inhibition of DC maturation. Furthermore, injection of the A2AR antagonist SCH58261 reversed IPC-induced inhibition of DC maturation and mitigated the protective effect of preconditioning, which further confirmed that DC maturation contributed to immune cell-mediated ischemic preconditioning.

DCs are the most important APCs that drive the maturation and polarization of naive $\mathrm{T}$ cells by recognizing specific MHC-presented antigenic peptides. The nature of the T-cell response dependent on DC status is determined by signals received by pattern recognition receptors, membrane-bound co-stimulation and cytokines [49, 50]. Immature DCs characterized by the expression of a few co-stimulatory molecules induce $\mathrm{T}$ cell death or skew differentiation towards a regulatory phenotype (Regulatory T Cell, Tregs) [51], and are thus considered tolerogenic. Immature DCs secrete higher level of IL-10 than do mature DCs, and IL-10 produced by DCs induces immune suppression by modulating CD $4^{+} \mathrm{T}$ cells [52]. Injection of immature DCs reduced renal IRI by generating more Tregs [53]. Other studies have indicated that the protective effect of immature DCs on the kidney is partly attributed to IL-10-mediated activation of Tregs [54]. In this study, we found that the IL-10 levels in the kidneys of the IPC + I/R group were elevated compared with those of the sham +IR group, suggesting that IPC inhibits DC maturation, resulting in elevated levels of IL-10 that act on $\mathrm{CD} 4^{+} \mathrm{T}$ cells/Tregs to suppress inflammatory responses. In contrast to the cytoprotective molecule IL-10, IL-17 produced by Thelper (Th) cells, known as Th17 CD4+T cells, is a critical proinflammatory mediator in renal damage following IRI $[55,56]$. Our findings indicated that IL-17 levels in the kidneys of the IPC+I/R group were decreased compared with those of the sham+ IR group. Our results implied that the DC-T cell interactions play crucial roles in the renal protective effect of IPC, however, the underlying mechanism needs to be further assessed.

Our previous observations indicated that the beneficial effect of renal IPC not only provides local protection butalso protects remote organs, suggesting that the preconditioning effect might also be systemically mediated [22]. Another study reported that circulating immune cells responding to an initial ischemic event could mediate decreased tissue injury after a second ischemic event [57]. In our present study, we found a higher percentage of splenic $\mathrm{CD} 11 \mathrm{c}^{+} / \mathrm{F} 4 / 80^{-}$cells with less surface expression of activation molecules at the initial renal ischemic event on day 5. More importantly, we observed that the alterations of splenocytes observed in renal IPC day 5 were reversed by systemically inhibiting maturation 


\section{Cellular Physiology Cell Physiol Biochem 2018;46:1807-1820 and Biochemistry Published online: April 30, $2018 \quad$\begin{tabular}{l|l} 
O 2018 The Author \\
www.karger.com/cpp
\end{tabular} \\ Zhang et al.: Delayed Ischemic Preconditioning Inhibits the Maturation of Dendritic Cells}

of $\mathrm{CD} 11 \mathrm{c}^{+} / \mathrm{F} 4 / 80^{-}$cells, further indicating that the renal protective effect of renal IPC is both local and systemic and exploring a potential mechanism of remote IPC.

Hypoxia and hypoxia-induced factor (HIF) lead to extracellular accumulation of adenosine, which allows tissues to adapt to hypoxia [58,59]. Adenosine has been known to have anti-inflammatory and tissue-protective effects by interacting with multiple receptors, such as A1AR, A2AR, and A2BR [60-62]. In particular, the activation of A2AR has been shown to protect kidney tissue from IRI. Li et al. demonstrated A2AR expressed on CD11 $\mathrm{c}^{+}$DCs served as a target for ex vivo modulation of DC function to block DC-mediated NKT cell activation in kidney IRI, and adenosine acts at A2AR on DCs to protect kidneys from injury [13]. In the current study, we extended the previous findings by demonstrating that injection of the A2AR antagonist SCH58261 increased maturation of CD11 ${ }^{+} /$F4/80-DCs and partly restored the protective effect of IPC on IRI. This finding does not only confirm the critical role of DCs in the protective effects of IPC but also indicates that IPC may protect kidneys from injury by causing accumulation of adenosine to activate A2AR on DCs. However, these findings can only show the association between DCs and AKI; to better clarify the exact role of DCs in ischemic preconditioning of the kidney, a DC depletion transgenic animal model should be applied. Further studies are needed to assess the effects of DCs in IPC using DC depletion transgenic animal model.

\section{Conclusion}

In summary, we provided evidence that renal IPC induced systemic and local immune tolerance by mediating the maturation status of the CD11 $\mathrm{c}^{+} / \mathrm{F} 4 / 80^{-} \mathrm{DC}$ subset. The beneficial effect of renal IPC is attributed to profound immunosuppression. Moreover, we demonstrated that inhibition of A2AR promoted maturation of $\mathrm{CD} 11 \mathrm{c}^{+} / \mathrm{F} 4 / 80^{-} \mathrm{DCs}$ and restored the protective effect of IPC. Identifying the mechanisms regarding IPC and its immunoregulatory effects could aid in the development of various strategies to enhance prevention or treatment of AKI.

\section{Acknowledgements}

This work was funded by the National Natural Science Foundation of China (81430015, 81570600 and 81670614), Shanghai Key Laboratory of Kidney and Blood Purification, Shanghai Science and Technology Commission (14DZ2260200), Talent Development Program of Zhongshan Hospital-Outstanding Backbone Project (2017ZSGG19) and Chinese Nephrology Young Physician Research Fund from China International Exchange and Promotion Association for Medical and Healthcare.

\section{Disclosure Statement}

No conflict of interests exists.

\section{References}

1 Luo F, Shi J, Shi Q, Xu X, Xia Y, He X: Mitogen-Activated Protein Kinases and Hypoxic/Ischemic Nephropathy. Cell Physiol Biochem 2016;39:1051-1067.

2 Mehta RL, Cerda J, Burdmann EA, Tonelli M, Garcia-Garcia G, Jha V, Susantitaphong P, Rocco M, Vanholder R, Sever MS, Cruz D, Jaber B, Lameire NH, Lombardi R, Lewington A, Feehally J, Finkelstein F, Levin N, Pannu N, Thomas B, Aronoff-Spencer E, Remuzzi G: International Society of Nephrology's 0 by 25 initiative for acute kidney injury (zero preventable deaths by 2025): a human rights case for nephrology. Lancet 2015;385:2616-2643.

3 Okusa MD, Molitoris BA, Palevsky PM, Chinchilli VM, Liu KD, Cheung AK, Weisbord SD, Faubel S, Kellum JA, Wald R, Chertow GM, Levin A, Waikar SS, Murray PT, Parikh CR, Shaw AD, Go AS, Chawla LS, Kaufman JS, Devarajan P, Toto RM, Hsu CY, Greene TH, Mehta RL, Stokes JB, Thompson AM, Thompson BT, Westenfelder CS, Tumlin JA, Warnock DG, Shah SV, Xie Y, Duggan EG, Kimmel PL, Star RA: Design of clinical trials in acute 


\section{Cellular Physiology Cell Physiol Biochem 2018;46:1807-1820 \begin{tabular}{l|l} 
DOI: 10.1159/000489366 & $\begin{array}{l}\text { ○ 2018 The Author(s). Published by S. Karger AG, Basel } \\
\text { www.karger.com/cpb }\end{array}$ \\
\hline
\end{tabular} \\ Zhang et al.: Delayed Ischemic Preconditioning Inhibits the Maturation of Dendritic Cells}

kidney injury: a report from an NIDDK workshop--prevention trials. Clin J Am Soc Nephrol 2012;7:851855.

4 Rana A, Goyal N, Ahlawat A, Jamwal S, Reddy BV, Sharma S: Mechanisms involved in attenuated cardioprotective role of ischemic preconditioning in metabolic disorders. Perfusion 2015;30:94-105.

5 Choi IY, Lee JC, Ju C, Hwang S, Cho GS, Lee HW, Choi WJ, Jeong LS, Kim WK: A3 adenosine receptor agonist reduces brain ischemic injury and inhibits inflammatory cell migration in rats. Am J Pathol 2011;179:20422052.

6 Fu J, Wang Y, Zhang L, Yu Z: Protective effect of liver ischemic preconditioning on rat hepatocytes. Sci China C Life Sci 2009;52:836-840.

7 Xu X, Kriegel AJ, Liu Y, Usa K, Mladinov D, Liu H, Fang Y, Ding X, Liang M: Delayed ischemic preconditioning contributes to renal protection by upregulation of miR-21 Kidney Int 2012;82:1167-1175.

8 Hausenloy DJ, Yellon DM: The second window of preconditioning (SWOP) where are we now? Cardiovasc Drugs Ther 2010;24:235-254.

-9 Mayer B, Soppert J, Kraemer S, Schemmel S, Beckers C, Bleilevens C, Rossaint R, Coburn M, Goetzenich A, Stoppe C: Argon Induces Protective Effects in Cardiomyocytes during the Second Window of Preconditioning. Int J Mol Sci 2016;17, 1159:

10 Wever KE, Menting TP, Rovers M, van der Vliet JA, Rongen GA, Masereeuw R, Ritskes-Hoitinga M, Hooijmans CR, Warle M: Ischemic preconditioning in the animal kidney, a systematic review and meta-analysis. PLoS One 2012;7:e32296.

11 Jiang SH, Liu CF, Zhang XL, Xu XH, Zou JZ, Fang Y, Ding XQ: Renal protection by delayed ischaemic preconditioning is associated with inhibition of the inflammatory response and NF-kappaB activation. Cell Biochem Funct 2007;25:335-343.

-12 Jurewicz M, Takakura A, Augello A, Naini SM, Ichimura T, Zandi-Nejad K, Abdi R: Ischemic Injury Enhances Dendritic Cell Immunogenicity via TLR4 and NF-kappa B Activation. Journal of Immunology 2010;184:2939-2948.

13 Li L, Huang L, Ye H, Song SP, Bajwa A, Lee SJ, Moser EK, Jaworska K, Kinsey GR, Day YJ, Linden J, Lobo PI, Rosin DL, Okusa MD: Dendritic cells tolerized with adenosine A(2A)R agonist attenuate acute kidney injury. Journal of Clinical Investigation 2012;122:3931-3942.

14 Hargadon KM: Murine and Human Model Systems for the Study of Dendritic Cell Immunobiology. Int Rev Immunol 2016;35:85-115.

15 Tadagavadi RK, Reeves WB: Renal dendritic cells ameliorate nephrotoxic acute kidney injury. J Am Soc Nephrol 2010;21:53-63.

16 Cho WY, Choi HM, Lee SY, Kim MG, Kim HK, Jo SK: The role of Tregs and CD11c(+) macrophages/dendritic cells in ischemic preconditioning of the kidney. Kidney Int 2010;78:981-992.

17 Zhou J, Zhong J, Lin S, Huang Z, Chen H, Tang S, Yang C, Fan Y: Inhibition of PTEN Activity Aggravates Post Renal Fibrosis in Mice with Ischemia Reperfusion-Induced Acute Kidney Injury. Cell Physiol Biochem 2017;43:1841-1854.

18 Wu H, Huang T, Ying L, Han C, Li D, Xu Y, Zhang M, Mou S, Dong Z: MiR-155 is Involved in Renal IschemiaReperfusion Injury via Direct Targeting of Fox03a and Regulating Renal Tubular Cell Pyroptosis. Cell Physiol Biochem 2016;40:1692-1705.

19 Yu X, Lu C, Liu H, Rao S, Cai J, Liu S, Kriegel AJ, Greene AS, Liang M, Ding X: Hypoxic preconditioning with cobalt of bone marrow mesenchymal stem cells improves cell migration and enhances therapy for treatment of ischemic acute kidney injury. PLoS One 2013;8:e62703.

20 Ling Q Yu X, Wang T, Wang SG, Ye ZQ Liu JH: Roles of the Exogenous H2S-Mediated SR-A Signaling Pathway in Renal Ischemia/ Reperfusion Injury in Regulating Endoplasmic Reticulum Stress-Induced Autophagy in a Rat Model. Cell Physiol Biochem 2017;41:2461-2474.

-21 Cohen-Fredarow A, Tadmor A, Raz T, Meterani N, Addadi Y, Nevo N, Solomonov I, Sagi I, Mor G, Neeman M, Dekel N: Ovarian dendritic cells act as a double-edged pro-ovulatory and anti-inflammatory sword. Mol Endocrinol 2014;28:1039-1054.

-22 Jia P, Wu X, Dai Y, Teng J, Fang Y, Hu J, Zou J, Liang M, Ding X: MicroRNA-21 Is Required for Local and Remote Ischemic Preconditioning in Multiple Organ Protection Against Sepsis. Crit Care Med 2017;45:e703-e710.

-23 Eberlin KR, McCormack MC, Nguyen JT, Tatlidede HS, Randolph MA, Austen WG, Jr: Ischemic preconditioning of skeletal muscle mitigates remote injury and mortality. J Surg Res 2008;148:24-30. 


\section{Cellular Physiology Cell Physiol Biochem 2018;46:1807-1820 \begin{tabular}{l|l} 
DOI: 10.1159/000489366 & $\begin{array}{l}\text { C 2018 The Author(s). Published by S. Karger AG, Basel } \\
\text { www.karger.com/cpb }\end{array}$ \\
\hline
\end{tabular} \\ Zhang et al.: Delayed Ischemic Preconditioning Inhibits the Maturation of Dendritic Cells}

24 Hausenloy DJ, Yellon DM: Remote ischaemic preconditioning: underlying mechanisms and clinical application. Cardiovasc Res 2008;79:377-386.

-25 Steinman RM, Cohn ZA: Identification of a novel cell type in peripheral lymphoid organs of mice. I. Morphology, quantitation, tissue distribution. J Exp Med 1973;137:1142-1162.

26 Banchereau J, Steinman RM: Dendritic cells and the control of immunity. Nature 1998;392:245-252.

27 Palucka K, Banchereau J: How dendritic cells and microbes interact to elicit or subvert protective immune responses. Curr Opin Immunol 2002;14:420-431.

28 Manicassamy S, Pulendran B: Dendritic cell control of tolerogenic responses. Immunol Rev 2011;241:206227.

29 Ganguly D, Haak S, Sisirak V, Reizis B: The role of dendritic cells in autoimmunity. Nat Rev Immunol 2013;13:566-577.

30 Solari MG, Thomson AW: Human dendritic cells and transplant outcome. Transplantation 2008;85:15131522.

-31 Hargadon KM: Tumor-altered dendritic cell function: implications for anti-tumor immunity. Front Immunol 2013;4:192.

-32 Lu L, Faubel S, He Z, Andres Hernando A, Jani A, Kedl R, Edelstein CL: Depletion of macrophages and dendritic cells in ischemic acute kidney injury. Am J Nephrol 2012;35:181-190.

-33 Li L, Okusa MD: Macrophages, dendritic cells, and kidney ischemia-reperfusion injury. Semin Nephrol 2010;30:268-277.

-34 Zhang MZ, Yao B, Yang S, Jiang L, Wang S, Fan X, Yin H, Wong K, Miyazawa T, Chen J, Chang I, Singh A, Harris RC: CSF-1 signaling mediates recovery from acute kidney injury. J Clin Invest 2012;122:4519-4532.

-35 Rogers NM, Ferenbach DA, Isenberg JS, Thomson AW, Hughes J: Dendritic cells and macrophages in the kidney: a spectrum of good and evil. Nat Rev Nephrol 2014;10:625-643.

-36 Ozaki KS, Kimura S, Nalesnik MA, Sico RM, Zhang M, Ueki S, Ross MA, Stolz DB, Murase N: The loss of renal dendritic cells and activation of host adaptive immunity are long-term effects of ischemia/reperfusion injury following syngeneic kidney transplantation. Kidney Int 2012;81:1015-1025.

-37 Choi JH, Cheong C, Dandamudi DB, Park CG, Rodriguez A, Mehandru S, Velinzon K, Jung IH, Yoo JY, Oh GT, Steinman RM: Flt3 signaling-dependent dendritic cells protect against atherosclerosis. Immunity 2011;35:819-831.

-38 Koltsova EK, Ley K: How dendritic cells shape atherosclerosis. Trends Immunol 2011;32:540-547.

-39 Kruger T, Benke D, Eitner F, Lang A, Wirtz M, Hamilton-Williams EE, Engel D, Giese B, Muller-Newen G, Floege J, Kurts C: Identification and functional characterization of dendritic cells in the healthy murine kidney and in experimental glomerulonephritis. J Am Soc Nephrol 2004;15:613-621.

40 Weisheit CK, Engel DR, Kurts C: Dendritic Cells and Macrophages: Sentinels in the Kidney. Clin J Am Soc Nephrol 2015;10:1841-1851.

41 Kim MG, Boo CS, Ko YS, Lee HY, Cho WY, Kim HK, Jo SK: Depletion of kidney CD11c+ F4/80+ cells impairs the recovery process in ischaemia/reperfusion-induced acute kidney injury. Nephrol Dial Transplant 2010;25:2908-2921.

42 Dong X, Swaminathan S, Bachman LA, Croatt AJ, Nath KA, Griffin MD: Resident dendritic cells are the predominant TNF-secreting cell in early renal ischemia-reperfusion injury. Kidney Int 2007;71:619-628.

-43 Yang CW, Li C, Jung JY, Shin SJ, Choi BS, Lim SW, Sun BK, Kim YS, Kim J, Chang YS, Bang BK: Preconditioning with erythropoietin protects against subsequent ischemia-reperfusion injury in rat kidney. FASEB J 2003;17:1754-1755.

44 Yamasowa H, Shimizu S, Inoue T, Takaoka M, Matsumura Y: Endothelial nitric oxide contributes to the renal protective effects of ischemic preconditioning. J Pharmacol Exp Ther 2005;312:153-159.

45 Liu F, Ni W, Zhang J, Wang G, Li F, Ren W: Administration of Curcumin Protects Kidney Tubules Against Renal Ischemia-Reperfusion Injury (RIRI) by Modulating Nitric Oxide (NO) Signaling Pathway. Cell Physiol Biochem 2017;44:401-411.

46 Lee HT, Emala CW: Preconditioning and adenosine protect human proximal tubule cells in an in vitro model of ischemic injury. J Am Soc Nephrol 2002;13:2753-2761.

\$7 Chen CB, Liu LS, Zhou J, Wang XP, Han M, Jiao XY, He XS, Yuan XP: Up-Regulation of HMGB1 Exacerbates Renal Ischemia-Reperfusion Injury by Stimulating Inflammatory and Immune Responses through the TLR4 Signaling Pathway in Mice. Cell Physiol Biochem 2017;41:2447-2460. 


\section{Cellular Physiology Cell Physiol Biochem 2018;46:1807-1820 and Biochemistry DOI: 10.1159/000489366 2018 ○ 2018 The Author(s). Published by S. Karger AG, Basel Zhang et al.: Delayed Ischemic Preconditioning Inhibits the Maturation of Dendritic Cells}

48 Soos TJ, Sims TN, Barisoni L, Lin K, Littman DR, Dustin ML, Nelson PJ: CX3CR1+ interstitial dendritic cells form a contiguous network throughout the entire kidney. Kidney Int 2006;70:591-596.

49 Ait-Oufella H, Sage AP, Mallat Z, Tedgui A: Adaptive (T and B cells) immunity and control by dendritic cells in atherosclerosis. Circ Res 2014;114:1640-1660.

50 Steinman RM: Decisions about dendritic cells: past, present, and future. Annu Rev Immunol 2012;30:1-22.

51 Bakdash G, Sittig SP, van Dijk T, Figdor CG, de Vries IJ: The nature of activatory and tolerogenic dendritic cell-derived signal II. Front Immunol 2013;4:53.

52 Pena C, Garate D, Contreras-Levicoy J, Aravena O, Catalan D, Aguillon JC: Dexamethasone preconditioning improves the response of collagen-induced arthritis to treatment with short-term lipopolysaccharidestimulated collagen-loaded dendritic cells. Clin Dev Immunol 2013;2013:296031.

53 Bajwa A, Huang LP, Kurmaeva E, Gigliotti JC, Ye H, Miller J, Rosin DL, Lobo PI, Okusa MD: Sphingosine 1-Phosphate Receptor 3-Deficient Dendritic Cells Modulate Splenic Responses to Ischemia-Reperfusion Injury. Journal of the American Society of Nephrology 2016;27:1076-1090.

-54 Kinsey GR, Huang L, Vergis AL, Li L, Okusa MD: Regulatory T cells contribute to the protective effect of ischemic preconditioning in the kidney. Kidney Int 2010;77:771-780.

55 Cortvrindt C, Speeckaert R, Moerman A, Delanghe JR, Speeckaert MM: The role of interleukin-17A in the pathogenesis of kidney diseases. Pathology 2017;49:247-258.

-56 Ornellas FM, Ornellas DS, Martini SV, Castiglione RC, Ventura GM, Rocco PR, Gutfilen B, de Souza SA, Takiya CM, Morales MM: Bone Marrow-Derived Mononuclear Cell Therapy Accelerates Renal IschemiaReperfusion Injury Recovery by Modulating Inflammatory, Antioxidant and Apoptotic Related Molecules. Cell Physiol Biochem 2017;41:1736-1752.

57 Burne-Taney MJ, Liu M, Baldwin WM, Racusen L, Rabb H: Decreased capacity of immune cells to cause tissue injury mediates kidney ischemic preconditioning. J Immunol 2006;176:7015-7020.

-58 Grenz A, Homann D, Eltzschig HK: Extracellular adenosine: a safety signal that dampens hypoxia-induced inflammation during ischemia. Antioxid Redox Signal 2011;15:2221-2234.

-59 Morote-Garcia JC, Rosenberger P, Kuhlicke J, Eltzschig HK: HIF-1-dependent repression of adenosine kinase attenuates hypoxia-induced vascular leak. Blood 2008;111:5571-5580.

-60 Lee HT, Gallos G, Nasr SH, Emala CW: A1 adenosine receptor activation inhibits inflammation, necrosis, and apoptosis after renal ischemia-reperfusion injury in mice. J Am Soc Nephrol 2004;15:102-111.

-61 Day YJ, Huang L, McDuffie MJ, Rosin DL, Ye H, Chen JF, Schwarzschild MA, Fink JS, Linden J, Okusa MD: Renal protection from ischemia mediated by A2A adenosine receptors on bone marrow-derived cells. J Clin Invest 2003;112:883-891.

-62 Grenz A, Osswald H, Eckle T, Yang D, Zhang H, Tran ZV, Klingel K, Ravid K, Eltzschig HK: The reno-vascular A2B adenosine receptor protects the kidney from ischemia. PLoS Med 2008;5:e137. 